\title{
Protein Profiling of Okra Genotypes Resistant to Root and Collar Rot Incited by Macrophomina phaseolina (Tassi) Goid. Using SDS-PAGE
}

\author{
T. Aravind ${ }^{\text {1* }}$ and A.B. Brahmbhatt ${ }^{2}$ \\ ${ }^{1}$ Department of Plant Pathology, G.B. Pant University of Agriculture and Technology, \\ Pantnagar, Uttarakhand - 263145, India \\ ${ }^{2}$ Department of Plant Pathology, Anand Agriculture University, Anand, \\ Gujarat-388110, India \\ *Corresponding author
}

Keywords

Okra, Root and Collar rot, Resistance, SDS PAGE

Article Info

Accepted:

18 October 2018

Available Online:

10 November 2018

\section{A B S T R A C T}

Root and collar rot of okra incited by Macrophomina phaseolina is an emerging problem in many parts of Gujarat. Twenty okra genotypes were screened for their resistance to root and collar rot under field conditions for two seasons. For further confirmation of the field results, variability in protein profile of resistant and susceptible genotypes was studied using SDS PAGE. Results revealed that protein profile of genotypes exhibited considerable variation from each other. Number of bands varied from four in highly susceptible variety to nine in resistant variety. Moderately resistant and susceptible genotypes had seven and six bands, respectively. The four genotypes were grouped into two clusters viz., cluster A (Resistant and moderately resistant) and cluster B which had two sub clusters $\left(\mathrm{B}_{1^{-}}\right.$Susceptible and $\mathrm{B}_{2^{-}}$Highly susceptible). Similarity coefficient ranged from $0.09-0.67$.

\section{Introduction}

Okra (Abelmoshus esculentus (L.) Moench) is an important annual vegetable grown throughout the tropical and subtropical regions of the world. It is mainly grown in India, Nigeria, Pakistan, Ghana, Egypt and Saudi Arabia. India rank first in area and production followed by Nigeria. In India, West Bengal is the leading producer followed by Gujarat (Anonymous, 2017). The biotic factors like pests and diseases hamper the successful cultivation of the crop.
The major diseases affecting the crop include okra yellow vein mosaic, Cercospora leaf spot, powdery mildew, etc. Root and collar rot incited by $M$. phaseolina, though not widely reported, is emerging as a major threat to okra cultivation especially in areas having prolonged dry spell. Macrophomina phaseolina is one of the most damaging primarily soil borne pathogens having heterogeneous host specificity. It infects about 500 plant species in more than 100 families throughout the world (Singh et al., 1990). The present study was undertaken to 
evaluate the okra germplasm against $M$. phaseolina and to validate the field results using SDS PAGE. Resistant germplasm may further be used in breeding programmes for development of disease resistant commercial cultivars.

\section{Materials and Methods}

Twenty different okra genotypes were screened for their resistance against root and collar rot incited by $M$. phaseolina under field conditions for two seasons (Summer and Kharif, 2016). The genotypes were grouped in to different resistance group based on percentage mortality as per Raj and Prasad (1975). Variability in the protein profile of one genotype from each of the resistance group (AOL-15-23- Resistant; AOL-15-21- Moderately resistant; AOL-1396- Susceptible; AOL-12-55- Highly susceptible) was studied with the help of "SDS PAGE (Sodium Dodecyl Sulphate Polyacrylamide Gel Electrophoresis)" as described by Laemmli (1970).

The okra plants for the experiment were raised in the pots contaminated with the pathogen mass multiplied in sand-maize medium. Collar portion of 20 days old seedlings (200 $\mathrm{mg}$ ) were homogenised in one $\mathrm{ml}$ of $0.1 \mathrm{M}$ phosphate buffer $(\mathrm{pH}$ 7.2) containing $30 \mathrm{mM}$ mercaptoethanol and two per cent SDS. The extract was centrifuged at $10,000 \mathrm{rpm}$ for $10 \mathrm{~min}$ at $4{ }^{\circ} \mathrm{C}$. The supernatant containing $50 \mu \mathrm{g}$ proteins was loaded for electrophoresis run. Proteins were separated using 5 per cent stacking and 12 per cent separating SDS polyacrylamide gel at $30 \mathrm{~mA}$ for three hours.

The gel was washed in double distilled water to remove excess SDS and stained for $4 \mathrm{hrs}$. Staining solution prepared by mixing $0.1 \mathrm{~g}$ coomassie brilliant blue R-250 in methanol: acetic acid: double distilled water (40: 10:
50). The gel was destained by using methanol: acetic acid and millipore water without dye. Dendrogram was developed using the principle of UPGMA (Unweighted Pair Group Method with Arithmetic Mean) software.

\section{Results and Discussion}

Protein profiling using SDS PAGE revealed that the genotypes exhibited variability in their protein profile (Fig. 1). The resistant genotype had nine bands, while the moderately resistant genotype had seven bands. The number of bands in susceptible and moderately susceptible genotypes was six and four respectively. Three protein bands were common in all the four varieties. The genotypes are grouped into two major cluster viz., A and B. Cluster A included the AOL-15-23 (Resistant) and AOL-15-21 (Moderately resistant) genotypes. Cluster B was subdivided into two sub-cluster $B_{1}$ and $\mathrm{B}_{2}$. Cluster $\mathrm{B}_{1}$ contained the susceptible genotype (AOL-13-96) while the cluster $\mathrm{B}_{2}$ included the highly susceptible genotype (AOL-12-55) (Fig. 2). The similarity coefficient ranged from $0.09-0.67$ within the four genotypes. Highest similarity coefficient was obtained between genotypes AOL-15-23 and AOL-15-21 (0.67) while AOL-15-23 and AOL-12-55 had the lowest similarity coefficient (0.09) (Table 1).

Aboshosha et al., (2008) have reported that a single protein band with 2-4 polypeptide bands was noted in healthy sunflower cultivars. The resistant cultivar had exhibited four protein bands, while most susceptible one exhibited two bands. Sunflower cultivars with intermediate susceptibility exhibited 3-4 bands and number of bands increased with increasing level of tolerance. The inoculation of the same sunflower cultivars with $M$. phaseolina resulted in protein bands with 7-9 polypeptide bands. 
Table.1 Jaccard's similarity coefficient between resistant and susceptible okra genotypes

\begin{tabular}{|c|c|c|c|c|}
\hline & AOL-15-23 & AOL-15-21 & AOL-13-96 & AOL-12-55 \\
\hline AOL-15-23 & 1.00 & & & \\
\hline AOL-15-21 & 0.67 & 1.00 & & \\
\hline AOL-13-96 & 0.27 & 0.44 & 1.00 & 1.00 \\
\hline AOL-12-55 & 0.09 & 0.10 & 0.43 & \\
\hline
\end{tabular}

Fig.1 Protein profile of okra genotypes

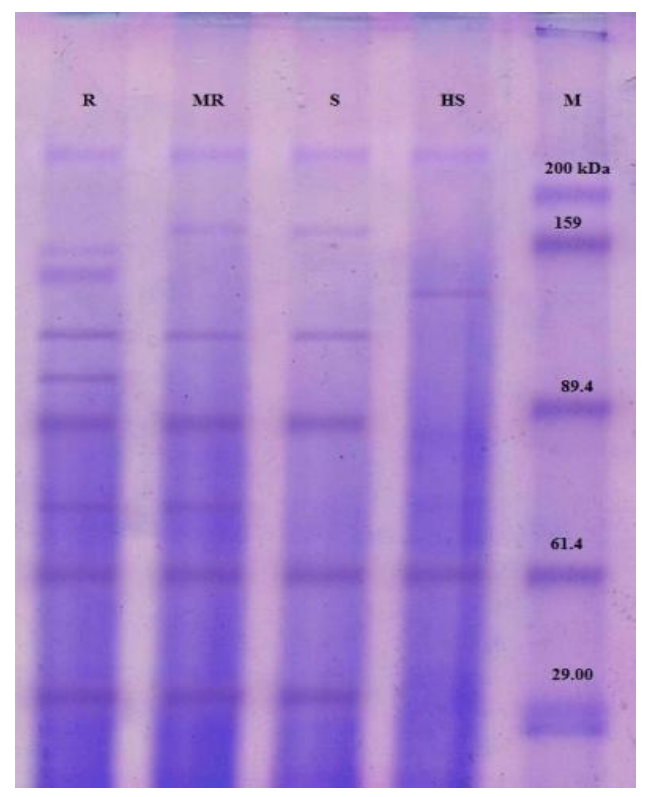

Fig.2 Dendrogram of okra genotypes developed using UPGMA software
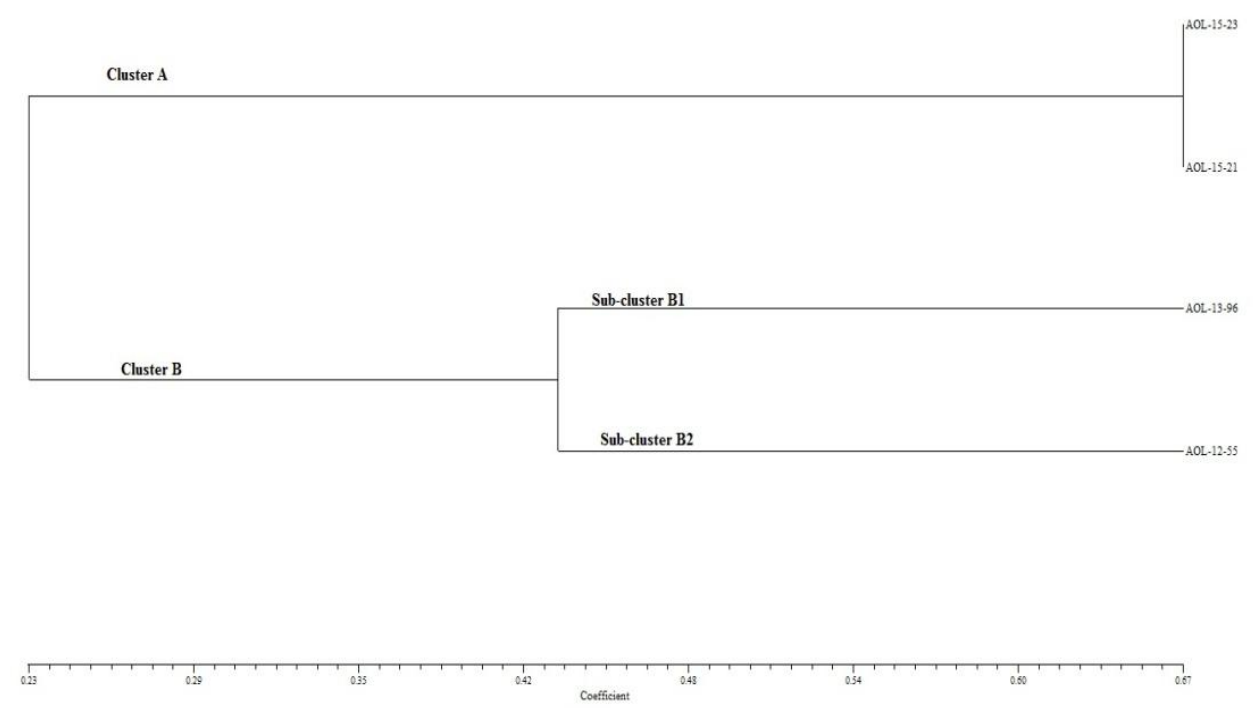
Similar conclusions have been made in other host-pathogen systems as well. In corn, kernals of genotypes resistant to Aspergillus flavus had relatively high concentration of 14 $\mathrm{kDa}$ protein which is absent or present in low concentration in susceptible genotypes (Chen et al., 1998). Similarly, Sapre et al., (2013) have reported that protein profile of pearl millet genotypes resistant to downy mildew had more number of bands (9-14) compared to susceptible genotypes (4-6). Thus, the expression of specific proteins is crucial in determining the final outcome of host pathogen interactions.

Thus, it can be concluded that the genotypes varying in the disease resistance to root and collar rot have differential gene expression and protein profile. The resistant genotype is having more number of bands which indicate a higher level of transcription and translation of specific proteins. These proteins may be involved in imparting disease resistance. However, further detailed investigation is required for characterization of the specific proteins and to identify their role in disease resistance.

\section{References}

Abhoshosha, S. S., Alla, S. S. A., ELKorany, A. E., El- Argawy, E. 2008. Protein analysis and peroxidase isozymes as molecular markers for resistance and susceptibility of sunflower to Macrophomina phaseolina. Int. J. Agri. Biol., 10(1): 2834.

Anonymous. 2017. Horticultural statistics at a glance- 2017; http://nhb.gov.in

Chen, Z. Y., Brown, R. L., Lax, A. R., Guo, B. Z., Cleveland, T. E. and Russin, J. S. 1998. Resistance to Aspergillus flavus in corn kernels is associated with a $14 \mathrm{kDa}$ protein. Biochem. Cell Biol. 88(4): 276-281.

Laemmli, U. K. 1970. Cleavage of structural proteins during the assembly of the head of bacteriophage T4. Nature, 227(52): 680-685.

Raj S. A., Prasad, N. N. 1975. Reaction of groundnut to Rhizoctonia bataticola (Macrophomina phaseolina). Indian Phytopathol. 28: 440-441.

Sapre, S. S, Singh, A., Saripalli, G. M., Patil, V. R. and Talati J. G. 2014. Characterization of downy mildew resistant and susceptible genotypes of pearl millet (Pennisetum glaucum L.) using SDS PAGE and RAPD markers. Agric. Sci. Dig. 34(3): 171-176.

Singh, S. K., Nene, Y. L. and Reddy, M. V. 1990. Influence of cropping systems on Macrophomina phaseolina population in soil. J. Pl. Dis.74: 812-814.

\section{How to cite this article:}

Aravind, T. and Brahmbhatt, A.B. 2018. Protein Profiling of Okra Genotypes Resistant to Root and Collar Rot Incited by Macrophomina phaseolina (Tassi) Goid. Using SDS-PAGE. Int.J.Curr.Microbiol.App.Sci. 7(11): 2290-2293. doi: https://doi.org/10.20546/ijcmas.2018.711.257 